\title{
Treatment of gonorrhoea with single oral doses of ampicillin plus probenecid I. Comparison with procaine penicillin
}

\author{
R. R. WILlCOX, K. R. WOODCOCK, D. LATTO, J. JOHN, AND A. REDMOND \\ St. Mary's Hospital, London \\ AND
}

R. B. PARKER, G. D. REES, AND R. J. C. COBBOLD

Mount Pleasant Hospital, Swansea

Ampicillin ( $\alpha$ amino-benzyl penicillin), the broadspectrum, acid-resistant, but not penicillinaseresistant penicillin, has now been used for the treatment of gonorrhoea for some years. Laboratory tests have shown it to be more active than benzyl penicillin against the less sensitive strains of gonococci (Ödegaard, 1962) and it has on this account been used with success in the treatment of patients failing to respond to benzyl penicillin (Willcox, 1964a; Smith, 1966). It gives excellent results when administered in multiple doses by mouth (Allen, 1970) or by injection (Kercull, 1968).

Given in single oral doses of up to $1 \mathrm{~g}$., the results obtained in London have not been as satisfactory as those achieved with $1.2 \mathrm{~m}$.u. aqueous procaine penicillin (Willcox, 1964b). Moreover the failure rates with the lower dosages have not been improved by increasing the single oral dose up to $2 \mathrm{~g}$. (Willcox, 1964b; McLone, Billings, Hardegree, and Hackney, 1968). However, better results with single oral doses of $1 \mathrm{~g}$. were reported from Liverpool by Alergant (1965) who claimed 95 per cent. success, although 6 years later in the Far East Kvale, Keys, Johnson, and Holmes (1971) were to experience no less than 29.3 per cent. of failures with single doses of $3.5 \mathrm{~g}$.

Better results, comparable to those obtained with $1.2 \mathrm{~m} . \mathrm{u}$. aqueous procaine penicillin, were obtained in London when two oral doses each of $1 \mathrm{~g}$. were given at an interval of $5 \mathrm{hrs}$ (Willcox, 1965). In Sweden, Groth and Hallquist (1970) claimed a success rate of 99-100 per cent. by this means, although they had the usual difficulties in distinguishing relapses from re-infections.

There are, however, considerable administrative and epidemiological advantages of a treatment which can be given under supervision at a single session. Venereal disease patients are seldom reliable in taking oral medicines at the times requested, and unconsumed tablets or capsules may be retained for self-treatment on a later occasion or for the treatment of others.
One single-session method which has been used satisfactorily is the combination of ampicillin by mouth with an injection of procaine penicillin (Gjessing and Ödegaard, 1965; Fluker and Hewitt, 1969), but this technique does not provide any administrative advantages and is not suited to those who fear injections or who are allergic to procaine.

A more favoured method is the use of probenecid which has been shown to enhance the blood levels of ampicillin (Robinson, 1964; Kvale and others, 1971). A few years ago, only 0.5 g. ampicillin by mouth plus probenecid sometimes provided a peak level exceeding the minimum inhibitory concentration (MIC) of the more resistant routine Far Eastern strains (Willcox, 1970).

The single oral dose of $3.5 \mathrm{~g}$. ampicillin which in the hands of Kvale and others (1971) has recently given quite unacceptable results in this area, was followed by only 4 per cent. of failures when probenecid was also given, although the four doses of probenecid used by these workers offered no administrative advantages. Also in the Far East, Keys, Halverson, and Clarke (1969), gave $2 \mathrm{~g}$. ampicillin by injection plus $1 \mathrm{~g}$. probenecid orally at one session and had only 1 per cent. of failures; in Norway, Gundersen, Ödegaard, and Gjessing (1969) had only 1.4 per cent. of failures when $2 \mathrm{~g}$. ampicillin orally was likewise combined with one dose of $1 \mathrm{~g}$. probenecid, and in Sweden Eriksson (1971) likewise reported only 0.9 per cent. of failures with this regime.

In view of the success obtained at St. Mary's Hospital using single injections of 1.2 m.u. aqueous procaine penicillin plus one oral dose of $1 \mathrm{~g}$. probenecid (Cobbold, Spitzer, Morrison, and Willcox, 1970), it was decided to determine the effect of single oral doses of ampicillin plus probenecid in London.

\section{Material}

114 male patients with acute uncomplicated gonorrhoea (101 at St. Mary's Hospital, London, and thirteen at 
King Edward VII Hospital, Windsor) were treated with $2 \mathrm{~g}$. ampicillin (four 500-mg. capsules) plus $1 \mathrm{~g}$. probenecid (two $0.5 \mathrm{~g}$. tablets) given together in a single oral dose, and a further 114 such patients were given single injections of $1.2 \mathrm{~m}$.u. aqueous procaine penicillin. The case material was similar in the two groups (Table I).

TABLE I Cases studied (all males)

\begin{tabular}{|c|c|c|}
\hline Treatment schedule & $\begin{array}{l}\text { Ampicillin plus } \\
\text { probenecid }\end{array}$ & $\begin{array}{l}1 \cdot 2 \text { m.u. procaine } \\
\text { penicillin }\end{array}$ \\
\hline No. of cases & 114 & 114 \\
\hline $\begin{array}{l}\text { Age (yrs) } \\
\text { Mean } \\
\text { Range }\end{array}$ & $\begin{array}{l}26 \cdot 9 \\
18-57\end{array}$ & $\begin{array}{l}29 \cdot 3 \\
17-54\end{array}$ \\
\hline No. married & 21 & 17 \\
\hline $\begin{array}{l}\text { Born in U.K. } \\
\text { No. } \\
\text { Per cent. }\end{array}$ & $\begin{array}{l}55 \\
48 \cdot 2\end{array}$ & $\begin{array}{l}48 \\
42 \cdot 1\end{array}$ \\
\hline $\begin{array}{l}\text { Previous VD } \\
\text { None } \\
\text { Attacks of GC } \\
\text { Attacks of NGU } \\
\text { Attacks of syphilis } \\
\text { Other } \\
\text { Average number of previous } \\
\text { attacks } \\
\text { Percentage with no previous } \\
\text { VD }\end{array}$ & $\begin{array}{c}52 \\
99 \\
21 \\
3 \\
5 \\
\\
1 \cdot 1 \\
45 \cdot 6\end{array}$ & $\begin{array}{r}49 \\
152 \\
25 \\
4 \\
6 \\
1.6 \\
43.0\end{array}$ \\
\hline $\begin{array}{l}\text { Duration of discharge (days) } \\
1-3 \\
4-7 \\
8-14 \\
\text { Longer than } 14\end{array}$ & $\begin{array}{r}70 \\
29 \\
12 \\
3\end{array}$ & $\begin{array}{r}71 \\
29 \\
8 \\
6\end{array}$ \\
\hline Complaint of dysuria & 83 & 60 \\
\hline $\begin{array}{cl}\text { Contracted from } \\
\text { Male } & \text { Stranger } \\
& \text { Friend } \\
\text { Female Stranger } & \\
& \text { Friend } \\
& \text { Wife }\end{array}$ & $\begin{array}{r}8 \\
6 \\
54 \\
44 \\
2\end{array}$ & $\begin{array}{r}6 \\
2 \\
58 \\
45 \\
3\end{array}$ \\
\hline
\end{tabular}

\section{Case management}

In all cases Neisseria gonorrhoeae were identified before treatment by Gram-staining of a urethral smear; in the diagnosis of gonorrhoea in the male, this method has been stated to be 99 per cent. accurate (Fiumara, 1972). Cultures were also made in some cases.

The two treatments were given to alternate cases under supervision. After treatment the patients were instructed to abstain from sexual intercourse and alcohol and to return after 2 to 3 days when the urethra was examined for discharge. A smear, and sometimes a culture, was taken if any discharge was present and the urine was examined for haze and threads. In none of the cases in which a follow-up culture was made were gonococci found which had not already been noted in the smear.

It was intended to repeat the surveillance approximately 1 and 2 weeks later, and subsequently 1,2 and 3 months after treatment. A routine serum test for syphilis was made at the outset and again at the end of the 3 months in those who attended. As commonly happens with venereal disease patients in a large metropolis, however, by no means all of them attended at the times intended.

\section{Results}

\section{PROCAINE PENICILIIN (Table II)}

Of the 114 patients treated, 98 were followed; the status at the last visit was satisfactory in 45 , further treatment was given for a non-gonococcal infection in 26 , seventeen were retreated for re-infection with gonorrhoea, and ten (10.2 per cent. of those followed) who denied further sexual exposure were regarded as treatment failures.

TABLE II Results obtained with procaine penicillin $1 \cdot 2$ m.u.

\begin{tabular}{|c|c|c|c|c|c|}
\hline $\begin{array}{l}\text { Duration of } \\
\text { follow-up }\end{array}$ & $\begin{array}{l}\text { No. } \\
\text { followed }\end{array}$ & $\begin{array}{l}\text { Satis- } \\
\text { factory }\end{array}$ & $\begin{array}{l}\text { Non- } \\
\text { gonococcal } \\
\text { infection }\end{array}$ & Re-infection & Failure \\
\hline 0 & 114 & - & - & - & - \\
\hline 1-3 days & 98 & 17 & 6 & 1 & 4 \\
\hline 4-7 days & 70 & 5 & 7 & 2 & 3 \\
\hline 8-14 days & 53 & 8 & 5 & 3 & 2 \\
\hline $15-21$ days & 35 & 2 & 5 & - & 1 \\
\hline $22-28$ days & 27 & 2 & 3 & 2 & - \\
\hline $1-2$ mths & 20 & 3 & - & 2 & - \\
\hline $2-3$ mths & 15 & 3 & - & 3 & - \\
\hline $\begin{array}{l}\text { More than } \\
3 \mathrm{mths}\end{array}$ & 9 & 5 & - & 4 & - \\
\hline Total & 98 & 45 & 26 & 17 & 10 \\
\hline
\end{tabular}

The difficulty of distinguishing relapses from re-infection is inherent in all therapeutic assessments of gonorrhoea. Curtis and Wilkinson (1958), on the basis of penicillin sensitivity tests, considered that if (regardless of history) all recurrences noted within 1 week of treatment were regarded as failures, and all of those noted after 1 week as re-infections, the picture obtained would not be far from the truth. Others have taken 2 weeks as a more realistic dividing line. In this series, if 1 week was taken, the number of failures was the same as if the patients had been assessed on history (10.2 per cent.), and if 2 weeks were taken there were fifteen recurrences $(15 \cdot 3$ per cent. of those followed).

\section{AMPICILLIN PLUS PROBENECID (Table III)}

Of the 114 patients treated 94 were followed; the status at the last visit was satisfactory in 39 , further treatment was given for a non-gonococcal infection in 31 , fourteen were re-treated for re-infection with gonorrhoea, and ten (10.6 per cent. of those followed), who denied further sexual exposure, were regarded as treatment failures. This was almost identical with the number of failures after treatment with $1.2 \mathrm{~m}$.u. procaine penicillin by injection, but if the recurrences noted within 2 weeks were taken, the failure rate 
(six failures) was only 6.4 per cent. of those followed, and if only 1 week was taken there were only five failures $(5 \cdot 3$ per cent.).

No side-effects were noted after treatment with ampicillin.

TABLE III Results obtained with ampicillin $2 \mathrm{~g}$. plus probenecid $1 \mathrm{~g}$.

\begin{tabular}{|c|c|c|c|c|c|}
\hline $\begin{array}{l}\text { Duration of } \\
\text { follow-up }\end{array}$ & $\begin{array}{l}\text { No. } \\
\text { followed }\end{array}$ & $\begin{array}{l}\text { Satis- } \\
\text { factory }\end{array}$ & $\begin{array}{l}\text { Non- } \\
\text { gonococcal } \\
\text { infection }\end{array}$ & Re-infection & Failure \\
\hline 0 & 114 & - & - & - & - \\
\hline $1-3$ days & 94 & 5 & 4 & - & 3 \\
\hline 4-7 days & 82 & 4 & 4 & - & 2 \\
\hline $8-14$ days & 72 & 7 & 8 & - & 1 \\
\hline 15-21 days & 56 & 3 & 4 & - & 2 \\
\hline $22-28$ days & 47 & 3 & 4 & 3 & 1 \\
\hline $1-2$ mths & 36 & 3 & 2 & 7 & 1 \\
\hline $2-3$ mths & 23 & 1 & - & 1 & - \\
\hline $\begin{array}{l}\text { More than } \\
3 \mathrm{mths}\end{array}$ & 21 & 13 & 5 & 3 & - \\
\hline Total & 94 & 39 & 31 & 14 & 10 \\
\hline
\end{tabular}

\section{Comparison of the two series (Table IV)}

As judged by regarding all recurrences as failures when encountered within 1 or 2 weeks regardless of a history of further sexual exposure, the results were substantially better after the oral ampicillin-probenecid combination than after $1.2 \mathrm{~m}$.u. procaine penicillin by injection.

Comparison with 2 g. of ampicillin in divided doses

A comparison is made in Table $\mathrm{V}$ of the results obtained with $2 \mathrm{~g}$. ampicillin plus probenecid with those of an earlier series, when the same dose of ampicillin but without probenecid was given in two oral doses each of $1 \mathrm{~g}$. at an interval of 5 hours (Willcox, 1965).

The combination of ampicillin and probenecid proved comparable in effectiveness with the same dose of ampicillin in two split oral doses given seven years earlier, in spite of any changes in the sensitivity of the gonococcus which may have occurred in the meantime (see under Discussion).

Comparison with $1.2 \mathrm{~m} . u$. procaine penicillin plus 1 g. probenecid

The results obtained with $2 \mathrm{~g}$. of ampicillin orally plus $1 \mathrm{~g}$. probenecid are compared in Table VI with those obtained in the same clinic using $1.2 \mathrm{~m} . \mathrm{u}$. procaine penicillin by injection plus $1 \mathrm{~g}$. probenecid (Cobbold and others, 1970).

TABLE IV Comparison of two series

\begin{tabular}{|c|c|c|c|c|c|c|c|c|}
\hline \multirow[b]{3}{*}{ Treatment schedule } & \multirow{3}{*}{$\begin{array}{l}\text { No. } \\
\text { treated }\end{array}$} & \multirow{3}{*}{$\begin{array}{l}\text { No. } \\
\text { followed }\end{array}$} & & & \multicolumn{4}{|c|}{ All recurrences } \\
\hline & & & \multicolumn{2}{|c|}{ Failures based on history } & \multicolumn{2}{|c|}{ Within 2 weeks } & \multicolumn{2}{|c|}{ Within 1 week } \\
\hline & & & No. & Per cent. & No. & Per cent. & No. & Per cent. \\
\hline $\begin{array}{l}1.2 \mathrm{~m} . \mathrm{u} \text {. } \\
\text { procaine penicillin }\end{array}$ & 114 & 98 & 10 & $10 \cdot 2$ & 15 & $15 \cdot 3$ & 10 & $10 \cdot 2$ \\
\hline $\begin{array}{l}\text { Ampicillin } 2 \mathrm{~g} \text {. plus } \\
\text { probenecid } 1 \mathrm{~g} \text {. }\end{array}$ & 114 & 94 & 10 & $10 \cdot 6$ & 6 & $6 \cdot 4$ & 5 & $5 \cdot 3$ \\
\hline
\end{tabular}

TABLE V Comparison of ampicillin plus probenecid in one dose with two split doses of ampicillin alone

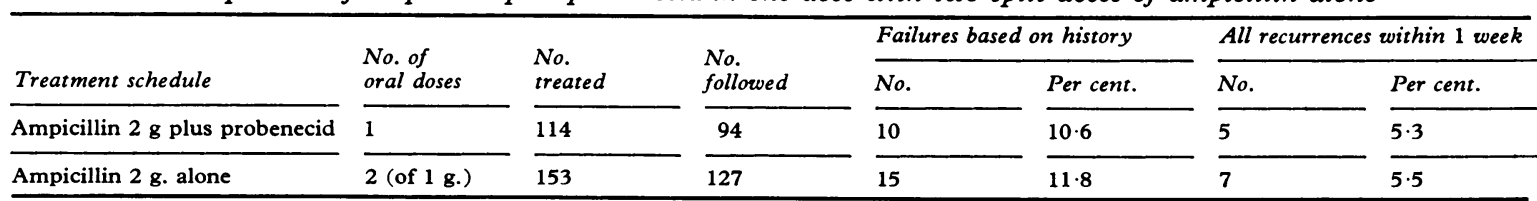

TABLE VI Comparison of ampicillin plus probenecid with procaine penicillin plus probenecid

\begin{tabular}{|c|c|c|c|c|c|c|c|c|}
\hline \multirow[b]{3}{*}{ Treatment schedule } & \multirow{3}{*}{$\begin{array}{l}\text { No. } \\
\text { treated }\end{array}$} & \multirow{3}{*}{$\begin{array}{l}\text { No. } \\
\text { followed }\end{array}$} & \multirow{2}{*}{\multicolumn{2}{|c|}{ Failures based on history }} & \multicolumn{4}{|c|}{ All recurrences } \\
\hline & & & & & \multicolumn{2}{|c|}{ Within 2 weeks } & \multicolumn{2}{|c|}{ Within 1 week } \\
\hline & & & No. & Per cent. & No. & Per cent. & No. & Per cent. \\
\hline $\begin{array}{l}\text { Ampicillin } 2 \mathrm{~g} . \text { plus } \\
\text { probenecid }\end{array}$ & 114 & 94 & 10 & $10 \cdot 6$ & 6 & $6 \cdot 4$ & 5 & $5 \cdot 3$ \\
\hline $\begin{array}{l}\text { Procaine penicillin } \\
1.2 \mathrm{~m} . \mathrm{u} \text {. plus probenecida }\end{array}$ & 307 & 264 & 18 & 6.8 & 19 & $7 \cdot 2$ & 11 & $4 \cdot 2$ \\
\hline
\end{tabular}


TABLE VII Results obtained with 1.2 m.u. procaine penicillin through the years

\begin{tabular}{|c|c|c|c|c|c|c|c|c|}
\hline \multirow[b]{2}{*}{ Year } & \multirow[b]{2}{*}{$\begin{array}{l}\text { No. } \\
\text { treated }\end{array}$} & \multirow{2}{*}{$\begin{array}{l}\text { No. } \\
\text { followed }\end{array}$} & & & \multicolumn{4}{|c|}{ All recurrences } \\
\hline & & & No. & Per cent. & No. & Per cent. & No. & Per cent. \\
\hline $\begin{array}{l}1961^{\mathrm{a}} \\
1963^{\mathrm{b}} \\
1966^{\mathrm{c}} \\
1968-69^{\mathrm{d}} \\
1970^{\mathrm{e}}\end{array}$ & $\begin{array}{l}200 \\
279 \\
200 \\
300 \\
114\end{array}$ & $\begin{array}{r}165 \\
207 \\
158 \\
264 \\
98\end{array}$ & $\begin{array}{l}25 \\
23 \\
17 \\
36 \\
10\end{array}$ & $\begin{array}{l}15 \cdot 2 \\
11 \cdot 1 \\
10 \cdot 8 \\
13 \cdot 7 \\
10 \cdot 2\end{array}$ & $\begin{array}{l}17 \\
\text { NR } \\
19 \\
34 \\
15\end{array}$ & $\begin{array}{l}10 \cdot 3 \\
\mathrm{NR} \\
12 \cdot 0 \\
12 \cdot 9 \\
15 \cdot 3\end{array}$ & $\begin{array}{r}15 \\
12 \\
9 \\
27 \\
10\end{array}$ & $\begin{array}{r}9 \cdot 1 \\
5 \cdot 8 \\
5 \cdot 7 \\
10 \cdot 2 \\
10 \cdot 2\end{array}$ \\
\hline
\end{tabular}

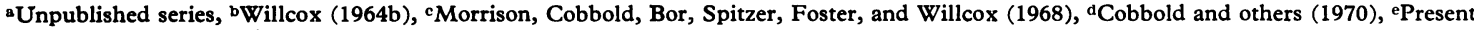
series, NR $=$ No record

\section{Discussion}

A difficulty in assessing the effectiveness of therapeutic regimes is that the sensitivity of the gonococcus to penicillin and other antibiotics varies geographically and with time, so that it may not be valid to compare the therapeutic results of one country or city with another, or indeed those obtained in the same city at different times.

However, the decreased sensitivity of the gonococcus to penicillin is more marked in the Far East (Keys and others, 1970), Africa (Arya and Phillips, 1970), and Australia (Hatos, 1970) than in Canada (Amies, 1969) and the U.S.A. (Fischnaller, Pedersen, Ronald, Bonin, and Tronca, 1968). The resistance is also much greater in North America than in northern Europe, e.g. in Scandinavia (Gundersen and others, 1969) and in the United Kingdom (Leigh, Le Franc, and Turnbull, 1969; Lynn, Nicol, Ridley, Rimmer Symonds, and Warren, 1970).

Although the proportion of less sensitive strains in London was reported from St. Thomas's Hospital to have increased between 1960 and 1966 (Nicol, Ridley, and Symonds, 1968), no such increase in resistance was noted by Leigh and others (1969) between strains isolated at St. Mary's in 1958 and 1968, and at St. Thomas's no further increase was observed between 1966 and 1968 (Lynn and others, 1970). The apparently static situation at St. Mary's is reflected by the results obtained in the treatment of gonorrhoea with $1.2 \mathrm{~m}$.u. aqueous procaine penicillin during the past 10 years which, although subject to variation, have shown no clear-cut deterioration irrespective of the method of assessment (Table VII).

It would seem, therefore, that therapeutic results of different regimes obtained through the years, if related to those simultaneously observed after single injections of $1.2 \mathrm{~m} . \mathrm{u}$. aqueous procaine penicillin, could be more meaningfully compared in London than in many other areas throughout the world.

\section{Summary and conclusions}

(1) The results of treating 114 male patients suffering from acute uncomplicated gonorrhoea with $2 \mathrm{~g}$. ampicillin plus $1 \mathrm{~g}$. probenecid given orally at a single session in London are compared with those observed in 114 alternate patients given single injections of $1 \cdot 2$ m.u. aqueous procaine penicillin.

(2) When all the recurrences noted within 1 or 2 weeks after treatment, regardless of a history of further sexual exposure, were regarded as failures, the results were substantially better when the ampicillinprobenecid combination was used.

(3) The single dose of ampicillin and probenecid gave similar results to those previously obtained by two oral doses, each of $1 \mathrm{~g}$. ampicillin, given 5 hours apart without probenecid. Indeed, the singledose treatment of ampicillin plus probenecid proved comparable in effectiveness to $1.2 \mathrm{~m} . \mathrm{u}$. procaine penicillin by injection plus probenecid by mouth.

(4) The single dose of ampicillin and probenecid given under supervision thus offers a treatment of gonorrhoea with all of the epidemiological advantages of the so-called 'single-shot', 'one-minute', or 'instant' treatments using a single injection, but with the added advantage of economy of labour, ease of administration, better patient acceptability, freedom of risk of procaine reactions, and probably also a lessened risk of serious allergic reactions to penicillin. (5) The results were nevertheless not as good as those obtained with $2 \mathrm{~g}$. ampicillin plus $1 \mathrm{~g}$. probenecid in Norway and Sweden.

\section{References}

Alergant, C. D. (1965) 'Ampicillin Therapy'. Excerpta Medica Foundation, 80

Allen, E. S. (1970) Brit. F. vener. Dis., 46, 334

AMIEs, C. R. (1969) Ibid., 45, 216

ARYa, O. P., and Phillips (1970) Ibid., 46, 149

Cobbold, R. J. C., SPItZer, R. J., Morrison, G. D., and Willcox, R. R. (1970) Postgrad. med. F., 46, 142 
Curtis, F. R., and Wilkinson, A. E. (1958) Brit. f. vener. Dis., 34, 70

ERIKsson, G. (1971) Acta-derm.-venereol. (Stockh.), 51, 305

Fischnaller, J. E., Pedersen, A. H. B., Ronald, A. R., Bonin, P., and Tronca, E. L. (1968) f. Amer. med. Ass., 203, 909

Fiumara, N. J. (1972) Med. Clin. N. Amer., 56, 1105

Fluker, J. L., and Hewitt, A. B. (1969) Brit. F. vener Dis., 45, 317

GJessing, H. C., and ÖdegaARd, K. (1965) Ibid., 41, 48

Groth, O. and Hallevist, L. (1970) Ibid., 46, 21

GUNDERSEN, T., ÖDEGAARD, K. and GJESSING, H. C. (1969) Ibid., 45, 235

Hatos, G. (1970) Med. F. Aust., 1, 1096

Kercull, R. G. (1968) Milit. Med. (Wash.), 133, 985

Keys, T. F., Halverson, C. W., and Clarke, E. J. (1969) f. Amer. med. Ass., 210, 857

Kvale, P. A., Keys, T. F., Johnson, D. W., and Holmes, K. K. (1971) Ibid., 215, 1449

Leigh, D. A., Le FranC, J., and Turnbull, A. R. (1969) Brit. F. vener. Dis., 45, 151

LynN, R., Nicol, C. S., Ridley, M., Rimmer, D., Symonds, M. A. E., and WARren, C. (1970) Ibid., 46, 404

McLone, D. G., Billings, T. E., Hardegree, W. E., and HACKNEY, J. F. (1968) Sth. med. F., 61, 278

Morrison, G. D., Cobbold, R. J. C., Bor, S., Spitzer, R. J., Foster, D. N., and Willcox, R. R. (1968) Brit. F. vener. Dis., 44, 319

Nicol, C. S., Ridley, M., and Symonds, M. A. E. (1968) Ibid., 44, 315

ÖDEgAARD, K. (1962) Brit. med. F., 1, 645

Robinson, O. P. W. (1964) Brit. F. clin. Pract., 18, 593

Smith, E. B. (1966) Milit. med. (Wash.), 131, 345

Willcox, R. R. (1964a) Brit. F. vener. Dis., 40, 118

- (1964b) Postgrad. med. F., 40, Suppl., p. 202

- (1965) Brit. F. clin. Pract., 19, 689

- (1970) Brit. F. vener. Dis., 46, 217
Traitement de la gonococcie par une dose buccale unique d'ampicilline plus probénécide

\section{Comparaison avec la pénicilline-procaïne}

\section{SOMMAIRE}

(1) Il y eut un contraste entre les résultats chez 114 hommes atteints de gonococcie aigüe non compliquée traités par $2 \mathrm{~g}$ d'ampicilline plus $1 \mathrm{~g}$ de probénécide donnée per os, prescrits en une seule séance à Londres, avec ceux observés chez 114 malades choisis par alternance et recevant une seule injection de 2 méga unités de pénicilline-procaïne aqueuse.

(2) Lorsque toutes les rechutes survenant une ou deux semaines après le traitement, sans tenir compte d'un risque sexuel, furent considérés comme des échecs, les résultats furent nettement meilleurs lorsque la combinaison ampicilline-probénécide fut employée.

(3) Une dose unique d'ampicilline plus probénécide permit des résultats identiques à ceux obtenus antérieurement lorsque deux doses buccales de chaque fois $1 \mathrm{~g}$ d'ampicilline avaient été prescrites à cinq heures d'intervalle, sans probénécide. En fait, le traitement par une dose unique d'ampicilline plus probénécide eut une efficacité comparable à celle de 1,2 méga unité de pénicillineprocaine par injection, plus probénécide.

(4) La méthode d'une dose unique, employant ampicilline et probénécide, lorsqu'elle est administrée sous surveillance, constitute donc un traitement de la gonococcie avec tous les avantages épidémiologiques de ce que l'on appelle le traitement 'en un coup', 'en une minute', 'en un instant', par une seule injection, avec l'avantage supplémentaire d'une économie de travail, de la facilité d'administration, de la meilleure acceptabilité par les malades, de la libération du risque de réactions allergiques sérieuses pouvant survenir aprés la pénicilline.

(5) Les résultats furent néanmoins moins satisfaisants que ceux obtenus en Norvège et en Suède par $2 \mathrm{~g}$ d'ampicilline plus $1 \mathrm{~g}$ de probénécide. 